\title{
Kazıcı Yükleyici Makineler için Kazıcı Kepçe ile Çalışan Hidrolik Bir Çene Tasarımı ve Denenmesi
}

\author{
Yusuf Ziya DEMIR ${ }^{1} \mathscr{\&}$, Yusuf USTA ${ }^{2}$ \\ ${ }^{1}$ Hidromek A.Ş., Araştırma Geliştirme ve Teknoloji Merkezi/, Ankara, Türkiye \\ ${ }^{2}$ Makine Mühendisliği Bölümü, Mühendislik Fakültesi, Gazi Üniversitesi, Ankara, Türkiye \\ $\bowtie$ : yusuf.demir@hidromek.com.tr
}

Geliş (Received): 08/04/2019

Düzeltme (Revision):25/04/2019

Kabul (Accepted): 13/06/2019

\section{öz}

Günümüzde birçok farklı inşaat işlerinin tamamlanabilmesi için kazıcı yükleyici makinelere ihtiyaç duyulmaktadır. $\mathrm{Bu}$ makineler önünde farklı yükleme işleri için yükleyici mekanizma grubu, arkasında ise farklı kazı işleri için kazıcı mekanizma grubu bulundurmaktadır. Yapılacak iş grubuna göre de farklı tip yükleyici ve kazıcı ataşmanları bulunmaktadır. Bu çalışmada kazıcı yükleyici makinelerin kazıcı tarafında kullanılan ve malzemelerin kavranarak yer değiştirilmesi ilkesine göre çalışan bir hidrolik çene mekanizması tasarlanmış ve prototip imalatı yapılmıştır. $\mathrm{Bu}$ tasarım ile makine üzerinde tahribata gerek olmayarak montaj edilebilen, amaca ve malzemeye göre ucu değiştirilebilen, ucun ters montajı yapılarak riper ataşmanı olarak da kullanılabilen mekanizma geliştirilmiştir. Tasarımı tamamlanan ataşmanın analizleri gerçekleştirilmiş, yapılan prototip üzerinde testler uygulanmış, böylece tasarım doğrulaması yapılarak uyumu incelenmiştir.

Anahtar Kelimeler: Çene tasarımı, hidrolik çene tasarımı, kazııı kepçe, kazıcı yükleyici makineler

\section{Design and Testing of a Hydraulic Thumb Design Working with Backhoe Bucket for Backhoe Loaders}

\begin{abstract}
Nowadays, backhoe loaders are needed to complete many different construction works. These machines have loader mechanism on the front side for different loading works beside; they have backhoe mechanism for different excavation works on the backside. According to the working group, there are different types of loader and backhoe attachments. In this study, a hydraulic backhoe thumb mechanism is designed and produced a prototype, which is used for backhoe side of the backhoe loaders and works by gripping the materials which is subjected to move. With the design, the thumb can be assembled on the machine without any destruction on the machine body, its toe can be replaced to the intended use and the material to be moved and can also be used as a riper attachment by reverse assembly of the toe. The analysis, production and testing of the attachment is carried out and the compatibility of the design with the analysis as well as the tests is examined.
\end{abstract}

Keywords: Backhoe buckets, backhoe loaders, hydraulic backhoe thumb design, jaw design

\section{GíRiş}

Kazıcı yükleyici iş makineleri günümüzde inşaat işlerinin birçoğunu yapma kabiliyetini bünyesinde bulunduran ve sektörde en yaygin kullanılan iş makinelerinden biridir. $\mathrm{Bu}$ makineler genel olarak kabin, şasi, güç aktarma elemanları, soğutma grubu elemanları ve hidrolik sistemler ile beraber ön tarafta yükleyici mekanizma grubu ve arka tarafta kazıcı mekanizma grubunun yer aldığı kazma ve yükleme işlerinde kullanılan iş makineleridir [1]. Mekanizma gruplarının hareketi hidrolik sistem vasitasıyla gerçekleşir. Yükleyici mekanizma grubu ile farklı ataşmanlar kullanılarak yığılı olan ya da kazı sonucunda ortaya çıkan malzemelerin araca yüklenmesinde veya kısa mesafede başka bir yere taşınmasında, yüzey tesviye işlemlerinde, malzeme küreme gibi birçok işlemlerde kullanılabilir. Kazıcı mekanizma grubuna uygun ataşmanlar kullanılarak da kanal ve diğer kazma işlemleri, sert zeminlerin kırılma ve yumuşatılmasında, araç yer değiştirmeden malzemelerin tutulup yer değiştirilmesi ya da malzemelerin yerleştirilmesi gibi farklı birçok iş gerçekleştirilebilir [2]. Bu işleri gerçekleştirmek amacıyla yükleyici kepçeler, forklift çatalları, tomruk yükleyici vs. gibi ataşmanlar yükleyici mekanizma grubu ile çalışırken, kazıcı kepçeler, polip, burgu, kırıcı vs. ataşmanlar ise kazıcı mekanizma grubu ile çalışır. Bu ataşmanlar genel kullanım amaçlı olup diğer ataşmanlara oranla daha sik tercih edilirler [3]. Ataşmanların kazıcı yükleyici makinelerde kullanımı Şekil 1'de gösterilmiştir.

Şekil 1'de gösterilen ataşmanlar kazıcı ve yükleyici mekanizma gruplarında çok sık kullanım alanı olan ataşmanlardır [4]. Fakat bu tip ataşmanların yanı sıra bir de işe özel ataşmanlar bulunmaktadır. Özel ataşmanlar genel kullanım amaçlı değil de belirli bir işin daha kolay 
ve kısa sürede yapılabilmesi için tasarlanan ataşmanlardır. Bu tip ataşmanlardan biri de kazıcı kepçe ile çalışan çene ataşmanlarıdır.

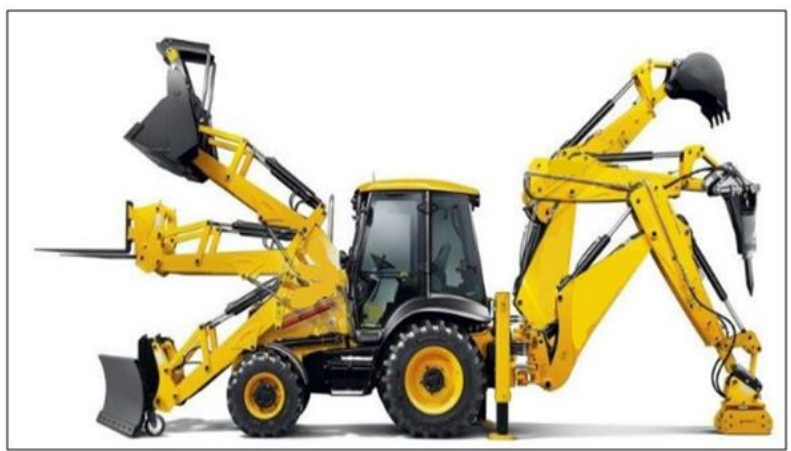

Şekil 1. Ataşmanların kazııı yükleyici makinelerde kullanımı

Günümüzde rekabetin arttı̆̆ı, zaman ile yarışıldığı, iş bitirme sürelerinin yakıt tüketimi, işletim giderleri, makine bakım giderleri ile doğru orantılı olduğu iş makineleri sektöründe özel ataşman kullanımının gelişmesi, geniş kullanım alanı olan kazıcı kepçe ile kullanılan çene ataşmanlarının da gelişmesinde büyük rol oynamıştır. Bu ataşmanlar, malzemelerin tutulup yer değiştirilmesi, malzemelerin kavranması gereken iş tanımları için özel olarak tasarlanmış ataşmanlardır.

Mekanik ve hidrolik olmak üzere genel olarak iki tip kazıcı kepçe ile çalışan çene ataşmanı bulunmaktadır. Mekanik çeneler (Şekil 2) herhangi bir hidrolik tertibat olmaksızın kazııı kepçeler ile çalışabilen ataşmanlardır. Genelde ilgili komponente kaynatılarak ya da montajlanarak iş makinelerine malzemeleri tutabilme özelliği kazandırırlar [5]. Maliyeti düşük olmasına karşın malzemelerin kavranması sadece kazıcı kepçenin hareketi ile gerçekleştirildiği için hidrolik tip çeneler kadar verimli değillerdir [6].
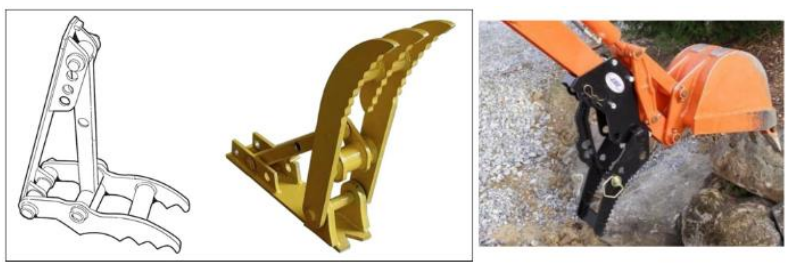

Şekil 2. Mekanik tip çeneler

Hidrolik çeneler makine üzerine kurulan hidrolik sistemden tahrik alarak bünyesinde bulundurduğu silindire hareket verir ve çenenin açılıp kapanması sağlanır (Șekil 3). Böylece operatör, kabinden çıkmaksızın kapasitesinin mümkün olduğu farklı boyutlardaki her türlü malzemeyi rahatça kavrayabilmektedir. Hem kazıcı kepçenin hem de hidrolik çenenin ayrı ve birbirinden bağımsız iki farklı silindir ile çalışmaları malzemelerin kavranabilmesinde operatöre büyük bir kolaylık sağlamaktadır [7]. Operatör kazıcı kepçeyi sabit pozisyonda tutarak sadece hidrolik çenenin hareketi ile çalışabilir ya da hem kazıcı kepçe hem de hidrolik çenenin ikisini birden hareket ettirerek çalışabilir. Bu tip çenenin de hareket edebildiği çalışma tarzı diğer çene tiplerine kıyasla işi daha kısa sürede bitirmeye olanak sağlar.

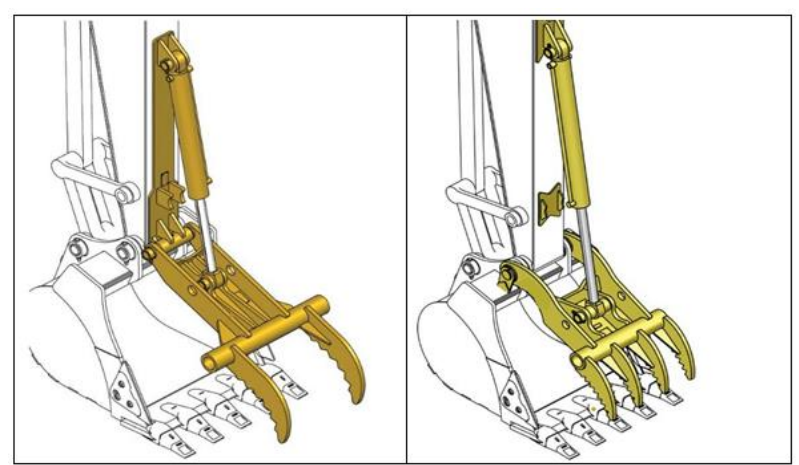

Şekil 3. Hidrolik tip çeneler

Hidrolik çenelerin kullanılabilmesi için makine üzerinde buna uygun bir hidrolik tesisatın bulunması ya da çene ile birlikte gerekli olan bu hidrolik tesisatın makine üzerine kurulması gerekmektedir. Genel olarak makinedeki uygun bir noktadan basınç ve diğer bir noktadan da tank hattı olmak üzere iki hat makineye takılan hidrolik çenedeki silindire beslenir. Böylece hidrolik çene silindirine hareket verilmiş olur [8]. Hidrolik tip çenelerin en büyük dezavantajı tüm bu hidrolik tesisat ve hidrolik silindirin sisteme getirdiği maliyettir. Ayrıca bakım gerektirmeyen, sadece yağlama periyotlarında silindirin her iki uç yataklarının yağlanması yeterli olacaktır. Böylece ilk yatırım maliyeti dışında makineye ek bir maliyet getirmemiş olacaktır. Mekanik tip çeneler ile bu yönden kıyaslandığında hidrolik tip çeneler dezavantajlıdır. $\mathrm{Bu}$ noktada, her iş makinesinde olmamak ile beraber makine üzerinde kazıcı mekanizma grubu üzerinde burgu, makas vs. gibi ataşmanların çalışmasını sağlayacak hidrolik tesisat bulunuyorsa hidrolik çene ataşmanını da çalıştırabilmek için bu hat kullanılabilir. Dolayısıyla eğer makine üzerinde böyle bir hidrolik tesisat varsa mekanik tip çeneler ile hidrolik tip çeneler arasındaki maliyet farkı ciddi miktarda azalacaktır. Hidrolik tip çenelerin en büyük avantajı ise verimliliktir. Operatör hidrolik çeneye de verdiği hareket ile malzemeleri kolayca kavrayabilecek ve çok daha kısa bir süre içerisinde mevcut işini bitirebilecektir. Bu tip çenelerin, malzemelerin kavranması esnasında manevra kabiliyeti çok yüksektir. Böylece kaya yerleşimi, yıkım, arazi temizleme, orman çalışmaları, tomruk yüklemeleri, hurdacılık vs. gibi geniş kullanım alanlarında daha kısa sürede iş tamamlama ve buna bağlı olarak düşük makine yakıt tüketimi, düşük iş̧̧ilik ücretleri ve işletim giderleri, uzun vadede daha seyrek makine bakım giderleri gibi ciddi avantajlar sağlayacaktır [9]. Şekil 4'te ataşmanın kullanıldığı çalışma alanlarından örnekler görülmektedir.

Özellikle kazıcı kepçe ile çalışan hidrolik çenelerin tasarım kriterleri ile ilgili standart bulunmamaktadır. Fakat bu çalışmada tasarımı yapılacak olan hidrolik çene, kullanım şekli ve amacı itibari ile nesne taşıma uygulamalarında kullanılmaktadır. 

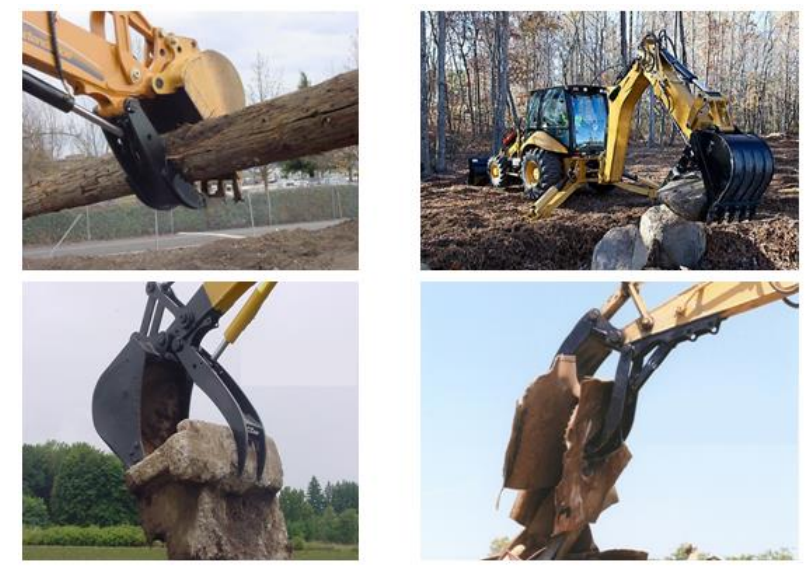

Şekil 4. Kazıcı kepçe ile çalışan çenelerin kullanım alanları

İş makinelerinde çene, polip, kanca vs. gibi ataşmanlar malzemelerin kavranıp yer değiştirme ilkesine göre çalıştığ tarafı nesne taşıma uygulamalarına (Object Handling Application) uymak zorundadır [10]. Bu standart genel olarak makine kaldırma ağırlığı, makine hidroliği kaldırma kapasitesi ve ilgili ataşmanla birlikte nesne taşıma uygulamalarında gerekecek güvenlik gereksinimlerini kapsamaktadır. Hidrolik çene ataşmanı ile nesne taşıma uygulamaları yapıldığı için makine üzerinde istenen güvenlik gereksinimleri bulunmalıdır. $\mathrm{Bu}$ zorunlu güvenlik gereksinimleri ise, makine maksimum kaldırma kapasitesi $1000 \mathrm{~kg}$ veya daha fazla; veya devrilme momenti $40000 \mathrm{Nm}$ ' ye eşit veya daha fazla olan makinelerde:

1- Deklare edilen kaldırma ağırlığı veya devrilme yükünün aşıldığı durumlarda sesli ya da görsel bir ikaz cihazının operatörü uyarması gerekmektedir. Bu uyarı cihazı nesne taşıma uygulamaları dışındaki kullanımlarda devre dışı bırakılabilir olmalıdır. Bu cihazın aktive edildiği de operatöre açık bir şekilde belirtilmelidir. Aktif/deaktif işlemlerini sağlayan tuşun konumu ise operatörün konfor bölgesi içerisinde olmalıdır. Nesne taşıma işlemi esnasında kontrol cihazının(tuşun) yanında ikaz cihazının aktive olduğunu belirten bir uyarıcı işaret olmalıdır [10].

2- Ayrıca kazıcı mekanizma grubunda bulunan kaldırıcı (bom) ve devirici (arm) silindir üzerlerinde hortum patlama valfleri olmalıdır. Devirici silindir üzerindeki kontrol cihazı kolun makineden uzaklaşıp yükselmesini sağlayan basınç tarafına konumlandırılmalıdır [10].

Tüm bu güvenlik gereksinimleri ataşmanın çalıştırılması için seçilen Hidromek marka kazıcı yükleyici makinelerinde farklı ataşmanlar ile yapılan nesne taşıma uygulamaları olduğu için makine üzerinde ilgili ataşmanla birlikte verilebilmektedir. Tasarımı yapılacak olan hidrolik çene ataşmanı kaldırma kapasitesi makinenin kaldırma kapasitesi ve devrilme yükü hesaplarının üstünde yapılmayacağı için makine bu ataşman ile birlikte kullanıldığında DIN EN 474-4 standardına uygun bir şekilde çalışacaktır.

Literatür çalışmalarında ayrıca ilgili patentler incelenmiştir. Böylece bu alan ile ilgili yenilikler, ataşman ile ilgili sorunlar ve dezavantajlara farklı yaklaşım ve çözüm önerileri ortaya koyulmuştur. Ayrıca bu çalışmada tasarımı yapılacak olan hidrolik tip çenenin tasarım kriterlerini oluşturmasına katkı sağlamıştır.

CN105256851A numaralı patent incelemesi (Şekil 5) [11].

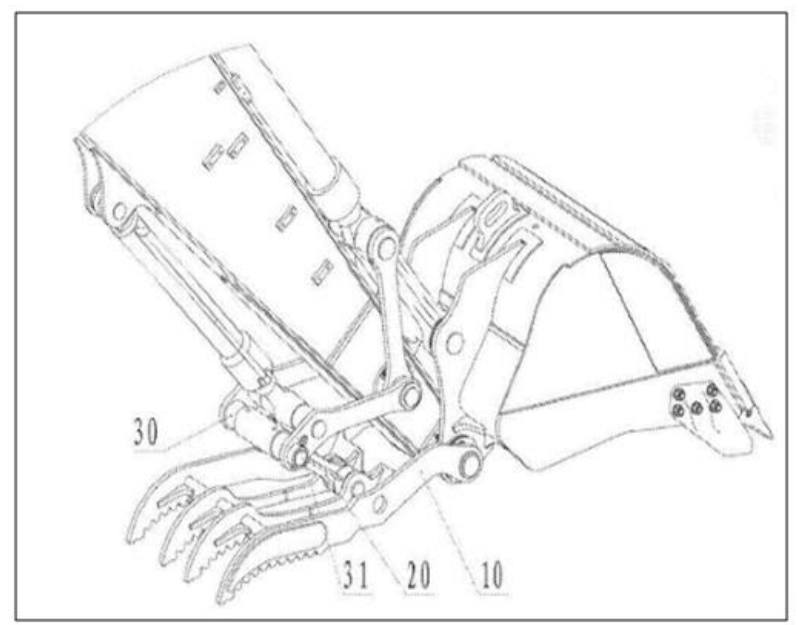

Şekil 5. CN105256851A numaralı patent

Avantajlar:

Farklı bağlantı yapısı ve silindir ile itici bağlantının farklı noktalarda çalışması ile çenenin daha fazla açma kapama açısına sahip olması,

\section{Dezavantajlar:}

- Hidrolik silindirin makine komponentine kaynaklı montajlanmasi,

- Bağlantı noktalarının nispeten fazla olması ile ayriyeten maliyet yükü,

- Çenenin tek parça olması, ileride yaşanabilecek çene uçlarının kırılması ya da hasar görmesi durumunda gövdenin tamamen değişmesi gerekecek ve farklı malzemeler için farklı tip uç kullanımına uygun olmamas1.

CN203383252U numaralı patent incelemesi (Şekil 6) [12].

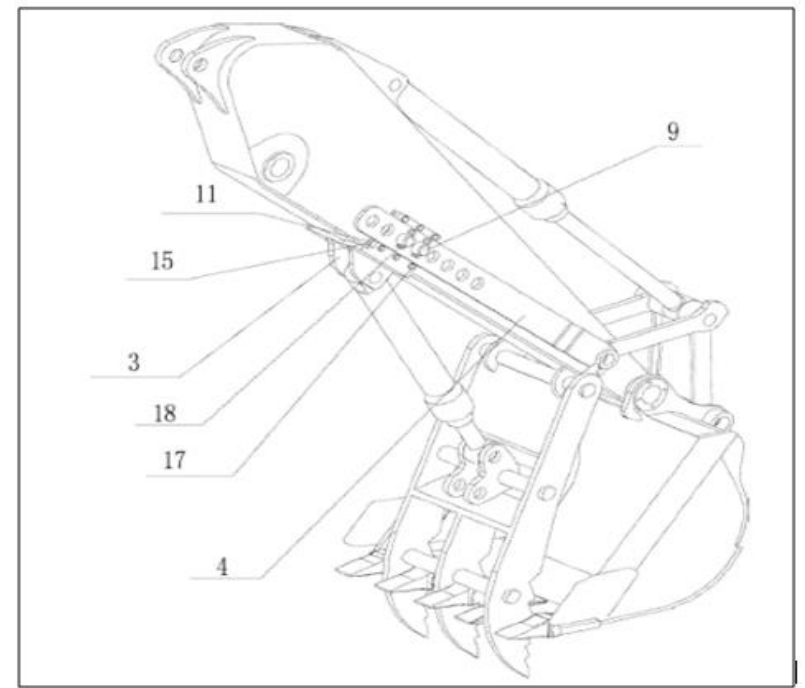

Şekil 6. CN105256851A numaralı patent 
Avantajlar:

- Silindirin montajı için makine üzerinde kaynaklı ya da farklı tip tahribata ihtiyaç duyulmaması,

- Silindirin makine üzerindeki piston tarafi bağlantı noktasının değiştirilebiliyor olması,

- Farklı bağlantı noktaları kullanılarak çenenin toplam açma kapama açısının değiştirilebiliyor olması,

- Silindirin çene üzerindeki mil tarafı bağlantı noktasının da iki farklı alternatifinin olması. Böylece silindirin piston tarafı bağlantı noktası değişiyorken mil tarafinda da ayrıca farklı bağlantı noktası kullanılarak mevcut arkalık bağlantı noktasında dahi çene açma kapama açısının değiştirilebiliyor olması.

Dezavantajlar:

- Silindir montajının makine üzerinde kaynaktan bağımsız bir şekilde montajlanabilmesi başarılabilmişken, çenenin bağlantı noktası için makine üzerine kaynaklı bağlantı noktalarının eklenmesi. Böylece makine, çenenin montaj1 için kaynak gerekliliğinden kurtarılamamıştır.

- Çenenin tek parça olması, ileride yaşanabilecek çene uçlarının kırılması ya da hasar görmesi durumunda gövdenin tamamen değişmesi gerekecek ve farklı malzemeler için farklı tip uç kullanımına uygun olmamasi.

JP2003213718A numaralı patent incelemesi (Şekil 7) [13].

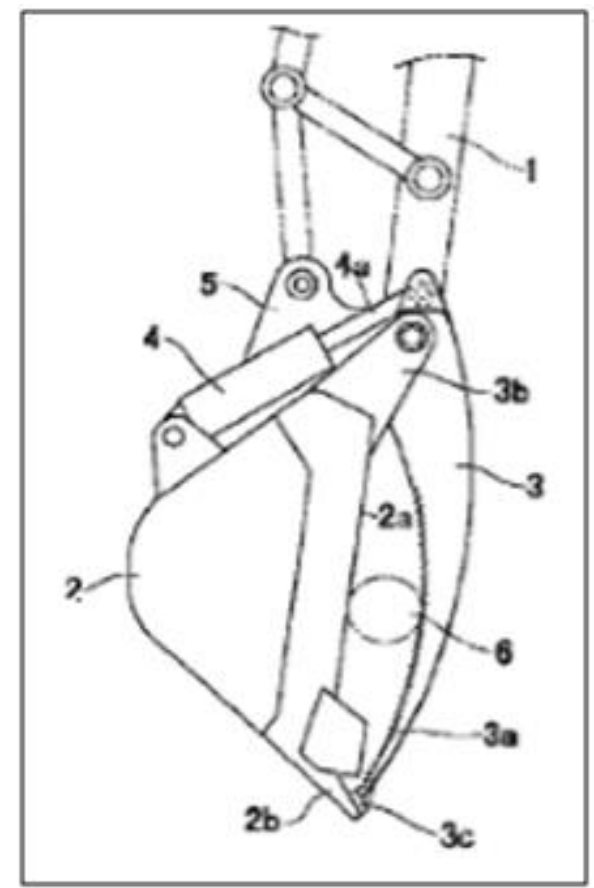

Şekil 7. CN105256851A numaralı patent

Avantajlar:

- Hidrolik çene ataşmanını tamamen makineden bağımsız kılarak kazıcı kepçe üzerinde konumlandırılmıştır. Böylece makine üzerinde yapılması gereken işlemler ortadan kalkmıştır.
Dezavantajlar:

- Hidrolik çene ataşmanı tamamen kazıcı kepçeye bağımlı hale getirilerek, müşterinin sonradan böyle bir ataşmanı istemesi durumunda kazıcı kepçe ile birlikte tedarik etmek zorunda kalması.

- Operatörün hidrolik çene ataşmanı ile işi bittikten sonra üzerindeki kepçe ile kazı vs. gibi işlemleri uygun bir şekilde yapabilmesi için silindir, çene vs. tüm bağlantıları ayrı ayrı sökmesi gerekecek.

- Çene tipi tek tip malzeme kavranabilmesi için tasarlanmış. Bu tip çene ile genelde yuvarlak kesitli, tomruk vs. gibi malzemelerin kavranması uygundur.

- Silindir kazıcı kepçe üzerinde konumlandırıldığı için buraya kadar kurulması gereken hidrolik tesisatlar malzeme ile çalışma alanına çok yakın kalacaktır. $\mathrm{Bu}$ da çalışma esnasında hidrolik hortumların malzeme ya da bir cisme teması ile zarar görmesine yol açabilir.

\section{MATERYAL ve YÖNTEM}

$\mathrm{Bu}$ çalışmada kaya yerleşimi, yıkım, arazi temizleme, orman çalışmaları, tomruk yüklemeleri, hurdacılık vs. gibi çalışma alanı oldukça geniş olan bir hidrolik çene ataşmanının tasarımı yapılmış, tasarım hesapları, analizleri ile üretimi ve testleri gerçekleştirilmiştir. $\mathrm{Bu}$ başlıklar altında rakip firmalar, ilgili patentler ve farklı ataşman üreticileri incelenerek piyasadaki bu tip ataşmanların avantaj ve dezavantajları araştırılmıştır. Buna göre farklı ve birçok avantajı bünyesinde bulunduran tasarım kriterleri belirlenmiş, bağlantı noktaları belirlenerek çenenin hareket yolu, açılma ve kapanma açıları vs. gibi bilgilerini içeren kinematik iskeleti oluşturulmuştur. Makinenin kaldırma kapasitesinden yola çıkarak ataşmanın kapasitesi belirlenmiştir. Daha sonra, belirlenen bu kinematiği ve kapasiteyi sağlayacak olan silindir hesapları ve tasarımı yapılmıştır. Kuvvet hesapları yapılarak piyasada oldukça geniş kullanım alanı bulunan SAE S355J2C+N ve aşınmaya dayanıklı saclar gibi ataşmana ait komponentlerin malzeme seçimi yapılarak ana gövde oluşturulmuştur. Creo 4.0 yazılımı ile tasarım tamamlanmıştır. Tasarımın tamamlanması ile birlikte hedeflenen sonuçlara ulaşan ataşmanın MSC Marc\&Mentat yazılımı ile sonlu elemanlar yöntemi analizi yapılmış ve yapılan tasarım doğrulamasının ardından prototip üretimi gerçekleştirilmiştir. Ataşman üzerinde belirlenmiş bölgelere gerinim-ölçerler montaj edilerek belirlenmiş yükler altında davranışı incelenmiş ve ticari olarak kullanılabilecek bir ürünün ortaya çıkması sağlanmıştır.

\section{Tasarım}

Literatür araştırmasının tamamlanması ile birlikte ataşmanın teknik özelliklerine karar verilmiştir ve öncelikle kinematik analizinin gerçekleştirilebilmesi için belirlenen teknik özellikleri sağlayan mekanizma noktaları ve mekanizmayı oluşturan uzuvların uzunlukları belirlenmiştir. 
Mekanizma noktaları belirlenirken çenenin hareketini kısıtlayacak olan ve makinenin kazıcı mekanizma grubu ile maksimum yükü kaldırabileceği pozisyon dikkate alınmıştır. Bu pozisyon, hacim kısıtı olarak makineye ait kaldırıcı kol (bom) ve devirici kol (arm) uzuvlarının birbirine doğru kapalı olduğu pozisyon iken, kaldırma ağırlığı kısıtı olarak da bom ve kolun makineye en yakın olduğu yürüyüş pozisyonudur. Makinenin bu pozisyonu Şekil 8'de gösterilmiştir. Bu pozisyonda dahi hidrolik çene sorunsuz bir şekilde açllıp kapanabilmeli, malzemeyi kavrayabilmelidir [14].

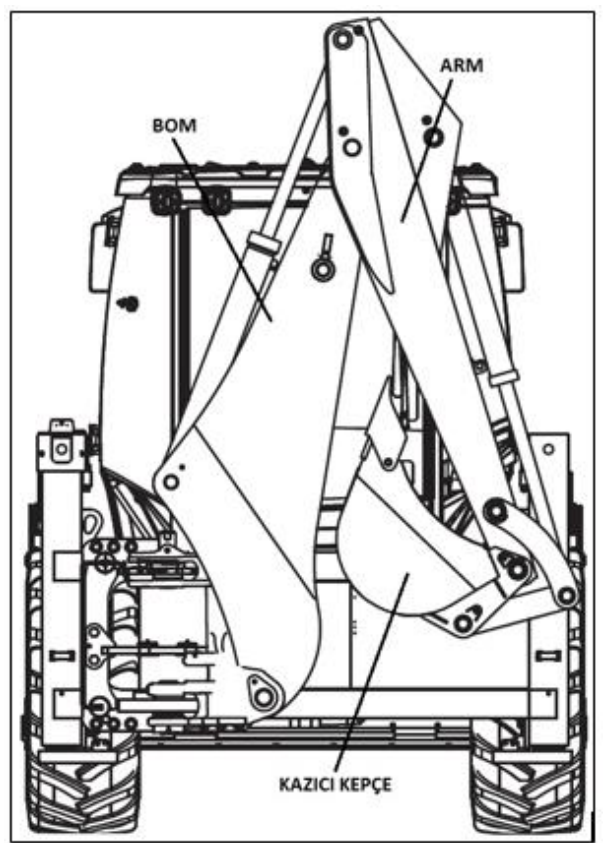

Şekil 8. Makine bom ve kolun kapalı olduğu pozisyon (yürüyüş pozisyonu)

Çenenin açılma açısının yanı sıra makineden bağımsız olarak çalışabilmesi için seçilen silindir bağlantı şeklinin dezavantajı olarak, silindir de çenenin hareketine bağımlı olarak makine üzerinde bir yay boyunca hareket edecektir. Silindirin hareketi için de kısıtlayıcı pozisyon kolun tam kapalı olduğu pozisyondur. Tüm bu kıstaslara göre ataşmanın ilk mekanizma noktaları ortaya çıkarılmıştır. Buna göre iki boyutlu yapılan çalışmalarda çenenin açık ve kapalı pozisyonları Şekil 9 ve Şekil 10'da gösterilmiştir.

Mekanizma noktaları belirlendikten sonra hidrolik çenenin kaldırma kapasitesi ve kuvvet hesapları yapılmıştır. Bunun için tasarımı yapılacak olan hidrolik çenenin uygulanacağı kazıcı yükleyici makinenin maksimum yükü kaldırabildiği pozisyonda, çenenin de bu yükü taşıyabilmesi hedeflenmiştir. Makinenin maksimum ağırlığı kaldırabildiği pozisyonda çenenin de bu ağırlığı kaldırabilmesi, diğer bütün pozisyonlarda ağırlık maksimum değerin üstüne çıkamayacağı için çene rahat bir şekilde çalışacaktır. Böylece makine daha yüksek bir ağırlığı kaldırabiliyorken çenenin kaldırma kapasitesinin daha az olmasından dolayı düşük ağırlıklarda çalışılması gerekmeyecek, makinenin kaldırma kapasitesinden taviz verilmeyecek ve verimlilik artacaktır.

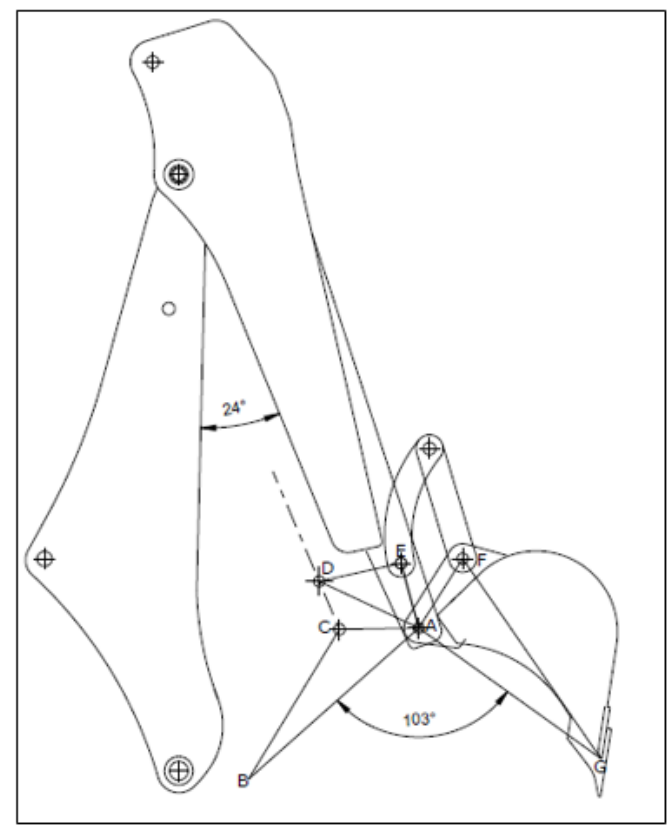

Şekil 9. Çenenin açık pozisyonu

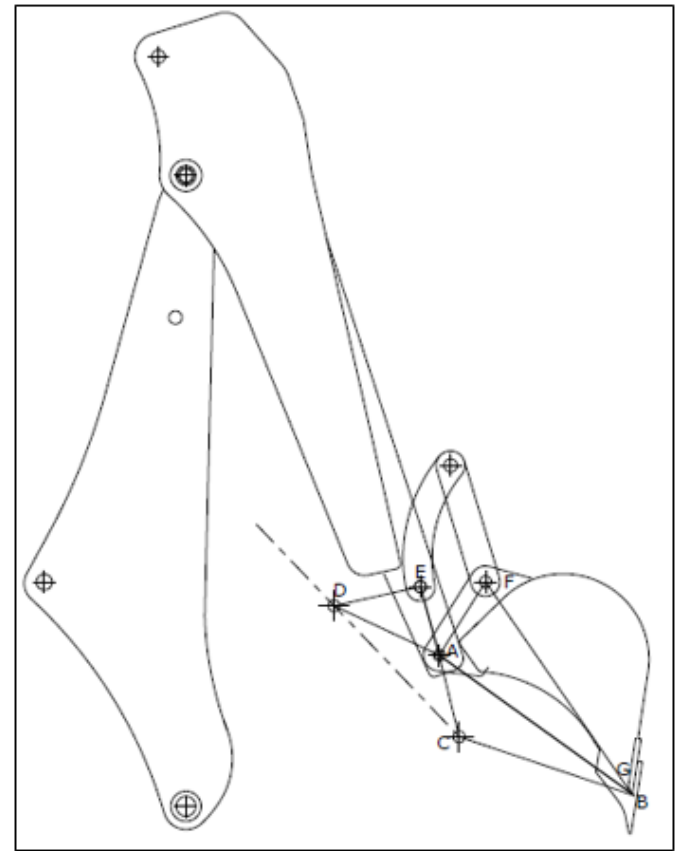

Şekil 10. Çenenin kapalı pozisyonu

Kazıcı yükleyici makinelerde kazıcı mekanizma grubunda ağırlık kaldırma işlemi sadece kolun hareketi ile kaldırma, sadece bomun hareketi ile kaldırma ve son olarak her iki uzvun da hareketi ile kaldırma olmak üzere üç farklı şekilde yapılabilir. Kaldırma kapasitesi hesaplarında sadece kol ya da sadece bom ile yapılan kaldırma hareketi kullanılır. Hidromek marka kazıcı yükleyici makinelerde kazıcı mekanizma grubunda bu her iki kaldırma tipi için de maksimum kaldırma kapasiteleri incelenmiştir. Sadece kolun hareketi ile 
kaldırma tipinde, kol ve bom tamamen kapalı pozisyonda moment kolu en düşük uzunlukta olduğu için makine en yüksek ağırlığı bu pozisyonda kaldırabilmektedir [15].

Yükün maksimum geleceği pozisyonun seçiminden sonra, bu pozisyonda Hidromek marka kazıcı yükleyici makinelerin kazıcı mekanizma grubu maksimum kol kaldırma kapasitesinden yola çıkılarak, makine bu maksimum ağırlığı hidrolik çene ile birlikte taşıdığında hidrolik çeneye gelen ağırlık hesaplanmıştır. Maksimum kuvveti kol kaldırma pozisyonunda kaldırabildiği için sadece kol dönü noktası (H noktası) hareket ederek kaldırma sağlanacaktır. A noktasında kaldırma kapasitesi makine katalog değerinde 2800 kg olarak verilmektedir. Buna göre kazıcı kepçe içerisindeki malzeme hidrolik çene ile kavrandığında $\mathrm{K}$ noktasından çene üzerine kuvvet uygulanmaktadır. $\mathrm{Bu}$ pozisyon Şekil 11'de gösterilmiştir. K noktasına uygulanan kuvvet hesaplanmıştır.

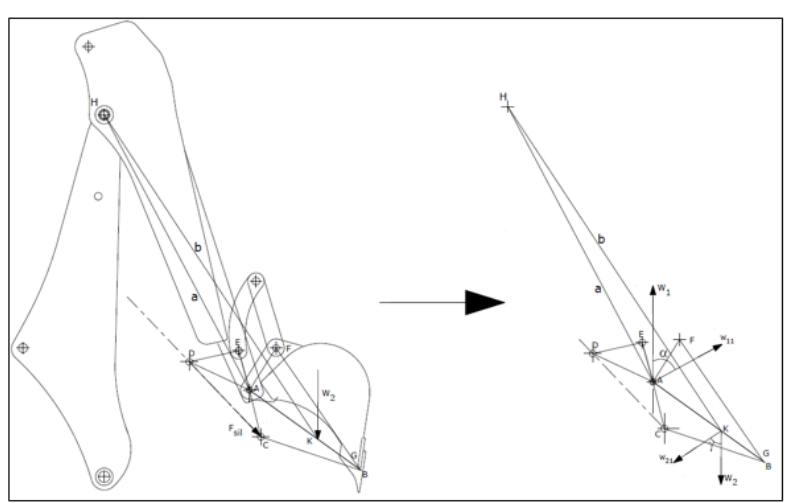

Şekil 11. Makine kaldırma kapasitesine göre çene kapasitesinin belirlenmesi

Burada:

HA uzunluğu; $a=2062 \mathrm{~mm}$

HK uzunluğu; $b=2574 \mathrm{~mm}$

$\alpha=62^{\circ}$

$\gamma=56^{\circ}$

$W_{1}=2800 \mathrm{Kg}=27468 \mathrm{~N}$

$W_{11}=W_{1} \cos \alpha=1314,52 \mathrm{Kg}=12895,44 \mathrm{~N}$

$W_{21}=W_{2} \cos \gamma$

Dönme noktası olan H noktasına göre moment alınırsa:

$\sum M_{H}=0$

$$
\begin{aligned}
& W_{11} a=W_{21} b \\
& W_{21}=1053 \mathrm{Kg}=10330,38 \mathrm{~N} \\
& W_{2}=1883 \mathrm{Kg}=18472,23 \mathrm{~N}
\end{aligned}
$$

Hidrolik çene üzerine 18472,23 N kuvvet geleceği görülmüştür.

Hidrolik çene kapalı iken kazıcı kepçe içerisinde kepçenin malzeme alabilen alanın ortasından (K noktası) çeneye uygulanan kuvvet en kötü şartlar temel alındığında 18472,23 N olarak hesaplanmıştır. Buradan yola çıkarak bu kuvvete karşı hidrolik çeneye hareket veren silindirin üretmesi gereken kuvvet hesaplanacaktır (Şekil 12) [16].

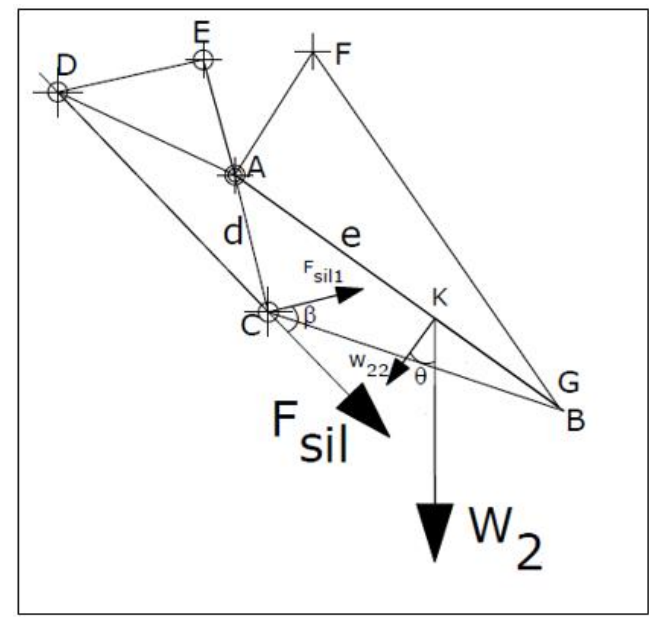

Şekil 12. Silindir kuvvetinin belirlenmesi

Burada:

AC uzunluğu; $d=319 \mathrm{~mm}$

AK uzunluğu; $e=556 \mathrm{~mm}$

$\beta=51,3^{\circ}$

$\theta=35,8^{\circ}$

$W_{2}=1883 \mathrm{Kg}=18472,23 \mathrm{~N}$

Dönme noktası olan A noktasına göre moment alınırsa:

$\sum M_{A}=0$

$W_{22} e=F_{\text {sil } 1} d$ 


$$
\begin{aligned}
& W_{2}=1883 \mathrm{Kg}=18472,23 \mathrm{~N} \\
& W_{22}=W_{2} \cos \theta=1527,23 \mathrm{Kg}=14982,15 \mathrm{~N} \\
& F_{\text {sil } 1}=26113,04 \mathrm{~N} \\
& F_{\text {sil }}=F_{\text {sil } 1} / \cos \beta \\
& F_{\text {sil }}=41764,64 \mathrm{~N}
\end{aligned}
$$

Hidrolik çene için gerekli olan silindir kuvveti 41764,64 $\mathrm{N}$ olarak hesaplanmıştır. Hidromek marka kazıcı yükleyici makinelerin hidrolik çalışma basıncı 230 bar'dır. Buradan yola çıkarak gerekli olan silindir piston çapı hesabı için [16]:

$$
\begin{aligned}
& P=230 \text { bar }=23 \mathrm{MPa} \\
& F=41764,64 \mathrm{~N} \\
& F=P A_{\text {piston }} \\
& A_{\text {piston }}=1815,85 \mathrm{~mm}^{2} \\
& A_{\text {piston }}=\pi r_{\text {piston }}^{2} \\
& r_{\text {piston }}=24,04 \mathrm{~mm} \\
& D_{\text {piston }}=48,08 \mathrm{~mm}
\end{aligned}
$$

Gerekli kuvveti oluşturması için piston çapı Ø48,08 mm olarak hesaplanmıştır. İmalat kolaylığı ve emniyetli bölgede kalınması açısından piston çapı Ø50 mm tasarlanacaktır.

Silindirin itme kuvvetini oluşturacak olan piston alanının tayininden sonra çekme kuvvetini belirleyen mil çapı flambaj hesapları yapılarak $\varnothing 30 \mathrm{~mm}$ olarak hesaplanmıştır. Mil çapları ayrıca Ø20 ve Ø25 için hesaplanmış fakat flambaj için uygun olmadığı için, emniyetli olan Ø30 mm mil çapı tasarımı yapılmıştır.

Flambaj hesabı için şuana kadar belirlenen silindir boyutları [17]:

Silindirin açık boyu: $s_{1}=1190 \mathrm{~mm}$

Silindirin kapalı boyu: $\mathrm{s}_{2}=708 \mathrm{~mm}$

$L_{\mathrm{ef}}=646 \mathrm{~mm}$

$$
\begin{aligned}
& D_{\text {piston }}=\varnothing 50 \mathrm{~mm} \\
& D_{\text {mil }}=\emptyset 30 \mathrm{~mm} \\
& \mathrm{~A}_{\text {piston }}=\pi r_{\text {piston }}^{2}=1963,49 \mathrm{~mm}^{2} \\
& \mathrm{~A}_{\text {mil }}=\pi \mathrm{r}_{\text {mil }}^{2}=706,85 \mathrm{~mm}^{2}
\end{aligned}
$$

Mil malzemesi olarak 20MnV6, C1050 ve Ck45 olmak üzere üç alternatif belirlenmiş olup bu üç malzemenin akma mukavemetleri sirasıla:

$$
\begin{aligned}
& \sigma_{20 M n V 6}=450 \mathrm{MPa} \\
& \sigma_{C 1050}=340 \mathrm{MPa} \\
& \sigma_{C k 45}=310 \mathrm{MPa}
\end{aligned}
$$

Tüm bu alternatif malzemeler arasında akma mukavemeti en düşük $\mathrm{Ck} 45$ malzeme seçilerek hesap yapılmıştır. Ayrıca elastisite modülü $\mathrm{E}=210000 \mathrm{MPa}$ alınmıştır. Ayrıca c sabiti 1 alınmıştır.

Atalet yarıçapının hesabı için:

$$
\begin{aligned}
& \text { Atalet yarıçapi }=K=\sqrt{\left(\mathrm{r}_{\text {mil }}^{2} / 2\right)+\left(\mathrm{L}_{\text {ef }}^{2} / 2\right)} \\
& \mathrm{K}=186,78 \mathrm{~mm} \\
& \mathrm{~L}_{\mathrm{ef}} / \mathrm{K}(\text { Gerçek })=3,45
\end{aligned}
$$$$
\mathrm{L}_{\mathrm{ef}} / \mathrm{K}(\text { Kritik })=\sqrt{\left.\left(2 \pi^{2} \mathrm{CE}\right) / \sigma_{C k 45}\right)}
$$$$
\mathrm{L}_{\mathrm{ef}} / \mathrm{K}(\text { Kritik })=115,63
$$

$\mathrm{L}_{\mathrm{ef}} / \mathrm{K}($ Kritik $)>\mathrm{L}_{\mathrm{ef}} / \mathrm{K}($ Gerçek $)$ olduğu için $F_{\text {kritik }}$ hesabında Johnson formülü kullanılacaktır.

$$
\begin{aligned}
& F_{\text {kritik,johnson }}=\left[\sigma_{C k 45}-\frac{\left[\frac{\sigma_{C k 45} \mathrm{~L}_{\mathrm{ef}}}{2 \pi \mathrm{K}}\right]^{2}}{\mathrm{CE}}\right] A_{\text {mil }} \\
& F_{\text {kritik,johnson }}=219025,48 \mathrm{~N} \\
& \text { Emniyet katsaylsı }=s=3 \\
& F_{\text {uygun }}=\frac{F_{\text {kritik }}}{S}
\end{aligned}
$$


$F_{\text {uygun }}=73008,49 \mathrm{~N}$

Makine çalışma basıncı $=23 \mathrm{MPa}$

$\mathrm{F}=\mathrm{P} A_{\text {piston }}$

$\mathrm{F}=45160,27 \mathrm{~N}$

$\frac{F_{\text {uygun }}}{F}>1$ olması gerekmektedir.

$\frac{F_{\text {uygun }}}{F}=1,6>1$ olduğu için $\emptyset 50 \mathrm{~mm}$ piston çap1 için $\emptyset 30 \mathrm{~mm}$ mil çapı uygundur.

Silindir boyutları hesaplandıktan sonra sızdırmazlık elemanları seçilerek silindir komplesi oluşturulmuştur. Daha sonra ayrı ayrı bağlantı elemanı, ana gövde ve uç tasarımı yapılmıştır.

Bağlantı elemanı tasarımı için:

Bağlantı elemanı, hidrolik çene ataşmanının uygulanacağı makine üzerinde herhangi bir tahribat oluşturmamak için çene ile makine arasında bağlantı görevi yapacak olan elemandır. A ve E noktaları makine üzerine bağlanırken, D noktası hidrolik silindir bağlantı noktasıdır (Şekil 13).

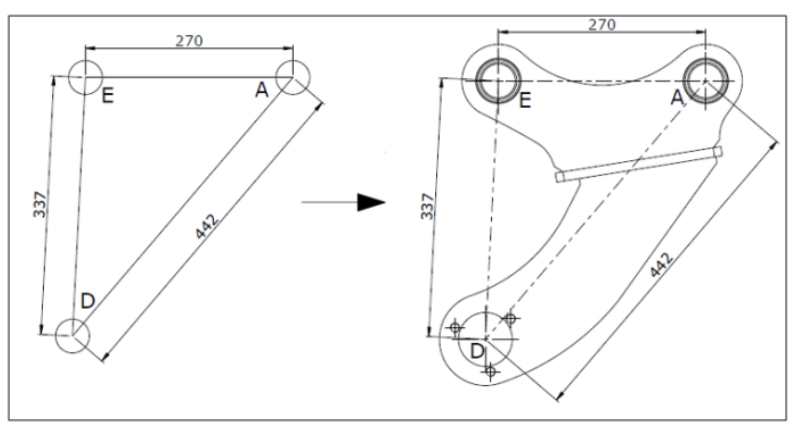

Şekil 13. Bağlantı elemanının hesaplanan sınırlar ile mukayesesi

Bağlantı elemanı, SAE S355J2C+N saclar, aşınmaya dayanıklı saclar ve S355J2 dolu malzemeler kullanılarak tasarlanmıştır (Şekil 14). Burada E ve A noktasını bünyesinde taşıyan sacın yekpare "U" bükümü şeklinde tasarlanması düşünülmüştür. Fakat bu bölgede analizlerden okunan yüksek gerilme değerleri sonucu mekanik özellikleri daha yüksek olan aşınmaya dayanıklı saclar ile tasarlanmıştır. Aşınmaya dayanıklı saclar daha sert oldukları için "U” büküme elverişli değildir. Dolayısıyla burada toplam üç sacın birbirine kaynatılması ile "U" kesit oluşturulmuştur. Aşınma kaygısı değil de mekanik özelliklerin daha üstün olmasından dolayı aşınmaya dayanıklı saclar bu bölgede tercih sebebidir. Tablo 1'de görüldüğü üzere, aşınmaya dayanıklı sacların sahip olduğu sertlik değeri bu sacları büküme elverişsiz k1larken (özellikle $90^{\circ}$ ve daha dar bükümlerde), S355J2C+N sacların büküme elverişli olduğu görülmektedir. Kaynaklanabilirlik özellikleri yaklaşık olarak aynıdır.

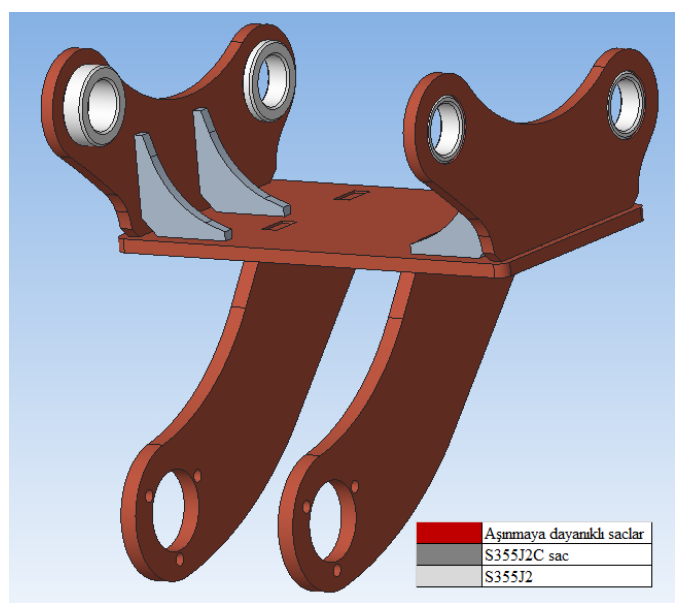

Şekil 14. Bağlantı elemanı tasarımı

Tablo 1. Malzeme Özellikleri

\begin{tabular}{cccc}
\hline $\begin{array}{c}\text { Malzeme/ } \\
\text { Özellikler }\end{array}$ & $\begin{array}{c}\text { Sertlik } \\
(\text { HBW) }\end{array}$ & $\begin{array}{c}\text { Akma } \\
\text { Mukavemeti } \\
\text { (MPa) }\end{array}$ & $\begin{array}{c}\text { Kalınlık } \\
(\mathbf{m m})\end{array}$ \\
\hline $\begin{array}{c}\text { S355J2C+N } \\
\text { Saclar }\end{array}$ & $146-187$ & 355 & $<16$ \\
$\begin{array}{c}\text { Aşınmaya } \\
\text { Dayanıklı } \\
\text { Saclar }\end{array}$ & $425-475$ & 1250 & $2,3-80$ \\
\hline
\end{tabular}

Bağlantı elemanı tasarımından sonra çene tasarlanmıştır. Burada piyasadaki genel kullanımın aksine değiştirilebilir ve $180^{\circ}$ döndürülerek malzeme sökme işlemleri için riper ataşmanı olarak da kullanımı amaçlanarak bu konuda 2019/02575 numaralı patent başvurusu yapılmıştır. Böylece çene, ana gövde ve uç olarak iki parça halinde tasarlanmıştır (Şekil 15).

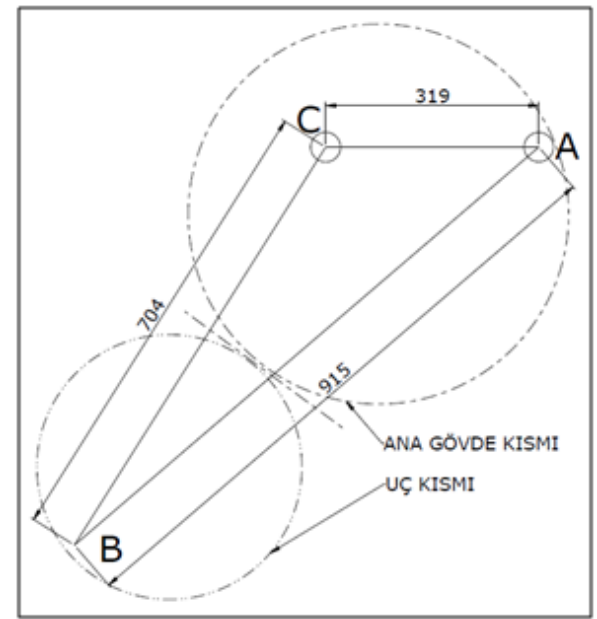

Şekil 15. Çene tasarımının iki parça olarak yapılması

Ana gövde tasarımı için:

Ana gövde, en başta belirlenen mekanizma noktalarına uyacak şekilde boyutlandırılarak üç boyutlu olarak tasarlanmıştır. Tasarım Şekil 16'da görülmektedir. Malzeme seçimi; gövdenin ana yapısı S355J2C+N sac, 
aşınmaya müsait bölgeler aşınmaya dirençli sac ve dönme noktası S355J2 dolu malzeme olarak üretimi planlanmıştır.

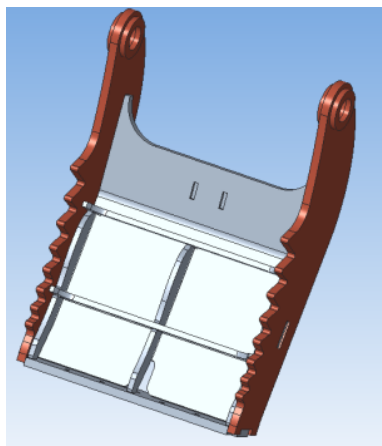

Şekil 16. Ana gövde tasarımı

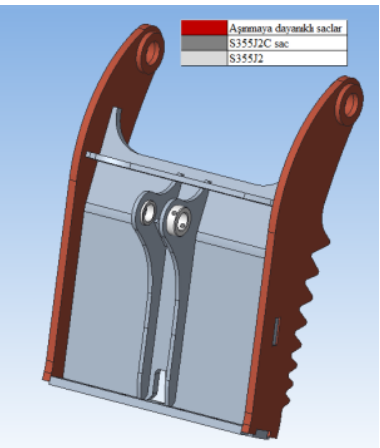

Ana gövde üzerinde malzemenin kavranması esnasında malzeme ile sürekli temas halinde çalışacak olan parçalar aşınmaya dayanıklı saclar ve malzemelerin kolay kavranması amaciyla kesim formunun dişli formda üretilmesi öngörülmüştür.

Uç tasarımı için:

Ana gövdeye cıvatalı bağlantılar ile montajlanarak ana gövde ile birlikte çeneyi oluşturmaktadırlar (Şekil 17). Ucun montajlı tasarlanmasi ile birlikte tek tip malzemelerin taşınmasında değil de malzemeye göre uç değiştirilerek tüm malzemelerin taşınabilmesinde kullanılabilecektir. Çalışma şartlarında uç sürekli malzemeler ile temas halinde olacağından ve özellikle riper ataşmanı olarak kullanımda malzemenin yerinden sökülmesinde kullanılacağından ucun genel yapısı aşınmaya dayanıklı saclar ile tasarlanmış ve bu saclar birbirleri ile EN 10305-3-E235 boru ile birbirleri arasında bağlanmıştır [18].
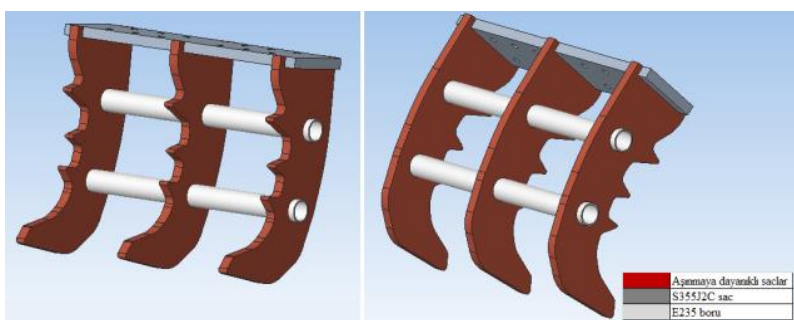

Şekil 17. Uç tasarımı

Uç tasarımında, ana gövde ile montajlandığında düzgün bir form izleyerek çeneyi oluşturması, yine sac kesim formuna verilen diş yapısı ile malzemenin kavranabilmesi ve uç kısmının hem malzemeyi kavrayabilmesi hem de çeneye ters montajlandığında riper ataşmanı olarak da çalışabilmesi için farklı bir kesim formuna sahip olması göz önünde bulundurulmuştur.

Ana gövde ve uç tasarımı ile birlikte çene yapısı ortaya çıkmıştır. Burada bağlantı noktalarının ve sınır noktalarının belirlenen mekanizma noktalarının ve sınırlarının içerisinde kalmasına dikkat edilmiştir (Şekil $18,19)$.

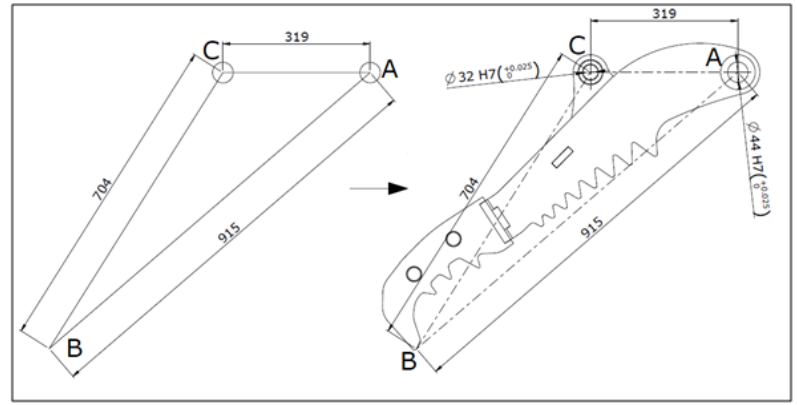

Şekil 18. Çene tasarımının hesaplanan sınırlar ile mukayesesi
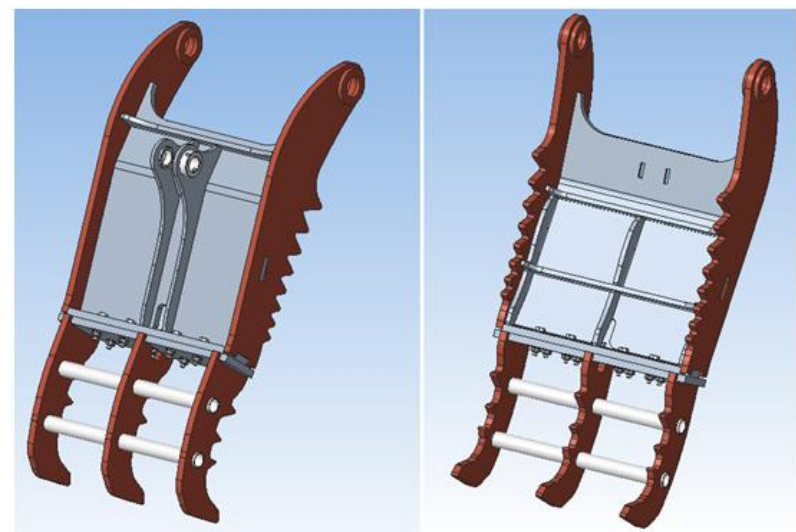

Şekil 19. Çene tasarımı

Çene komplesi için cıvata hesabı:

İlk olarak çene ile ucu birleştiren cıvata hesabı için bu bölgede serbest cisim diyagramı Şekil 20'deki gibi çizilmiştir. Çeneye etki eden 3 kuvvet vardır (ağırlık ihmal edilebilir). Fs silindir kuvveti $\mathrm{F}_{\mathrm{s}}=\mathrm{PA}$ olarak daha önce hesaplanmıştı. Cisim kola bağlı olduğundan $F_{g}$ etki-tepki kuvveti ve $F_{1}$, çenenin uygulayabileceği maksimum kuvvet altında statik dengede olacaktır. $F_{1}$ çeneye dik olacak şekilde alınmıştır. Bu üç kuvvet altında dengede olduğunda cisme etki eden kuvvetler toplamı sifir olmalı ve kuvvetler bir noktada kesişmelidir.

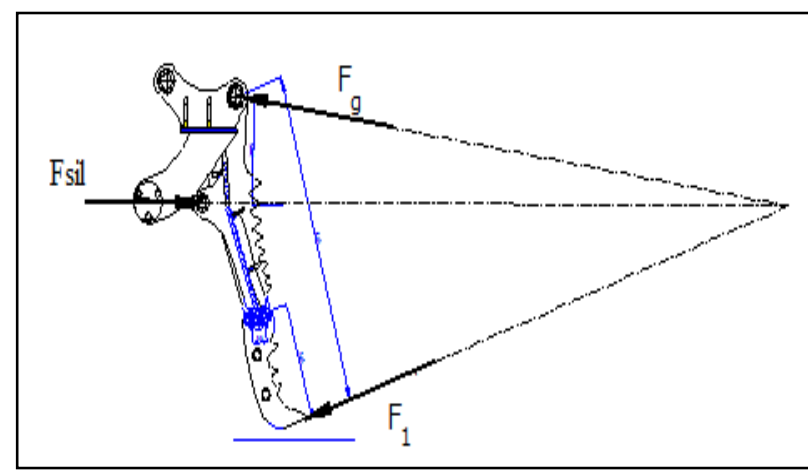

Şekil 20. Civata hesabı için serbest cisim diyagramı

$\mathrm{F}_{\text {sil }}+\mathrm{F}_{g}+\mathrm{F}_{1}=0$

Ayrıca Şekil 21'deki gibi konum analizi yapılarak gerekli açılar ve boyutlar bulunmuştur. 


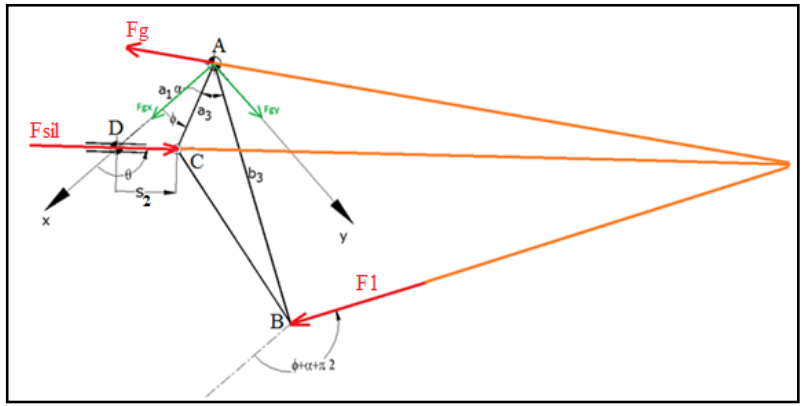

Şekil 21. Kuvvetlerin ve harekete göre birbirine bağımlı açıların tayini

a1, a3, b3 bilinen boyutlar, s ise pistonun konumudur. $\theta$ ve $\phi$ açıları cosinus teoremi kullanılarak bulunmuştur:

$\phi=\cos ^{-1}\left[\frac{\mathrm{a}_{1}{ }^{2}+\mathrm{a}_{3}{ }^{2}-\mathrm{s}_{2}{ }^{2}}{2 \mathrm{a}_{1} \mathrm{a}_{3}}\right]$

$\theta=\pi-\cos ^{-1}\left[\frac{a_{1}^{2}-a_{3}^{2}+s_{2}^{2}}{2 a_{1} s_{2}}\right]$

$\phi$ ve $\theta$ açıları bulunduktan sonra statik denge durumuna göre:

$\sum F_{x}=0 \quad \sum F_{y}=0 \quad \sum M=0$

Denklemleri yazılırsa:

$F_{s i l} \cos \theta-F_{1} \cos \left(\alpha+\phi+\frac{\pi}{2}\right)+F_{g x}=0$

$F_{s i l} \sin \theta-F_{1} \sin \left(\alpha+\phi+\frac{\pi}{2}\right)+F_{g y}=0$

Sadeleştirilirse:

$F_{s i l} \cos \theta+F_{1} \sin (\alpha+\phi)+F_{g x}=0$

$F_{s i l} \sin \theta-F_{1} \cos (\alpha+\phi)+F_{g y}=0$

Ve moment denklemi yazılırsa:

$F_{\text {sil }} a_{3} \sin (\theta-\phi)-F_{1} b_{3}=0$

3 numaralı denklem $F_{1}$ için çözülürse:

$F_{1}=F_{\text {sil }} \frac{a_{3}}{b_{3}} \sin (\theta-\phi)$

1 ve 2 numaralı denklemlerden:

$$
\begin{aligned}
& F_{g x}=-F_{s i l} \cos \theta-F_{1} \cos \left(\alpha+\phi+\frac{\pi}{2}\right) \\
& F_{g y}=-F_{s i l} \sin \theta-F_{1} \sin \left(\alpha+\phi+\frac{\pi}{2}\right) \\
& F_{g}={\sqrt{{F_{g x}}^{2}+{F_{g y}}^{2}}}^{2}
\end{aligned}
$$

Cıvatalara etki eden kuvvetleri bulmak için uç parçanın serbest cisim diyagramı Şekil 22'deki gibi çizilmiştir.

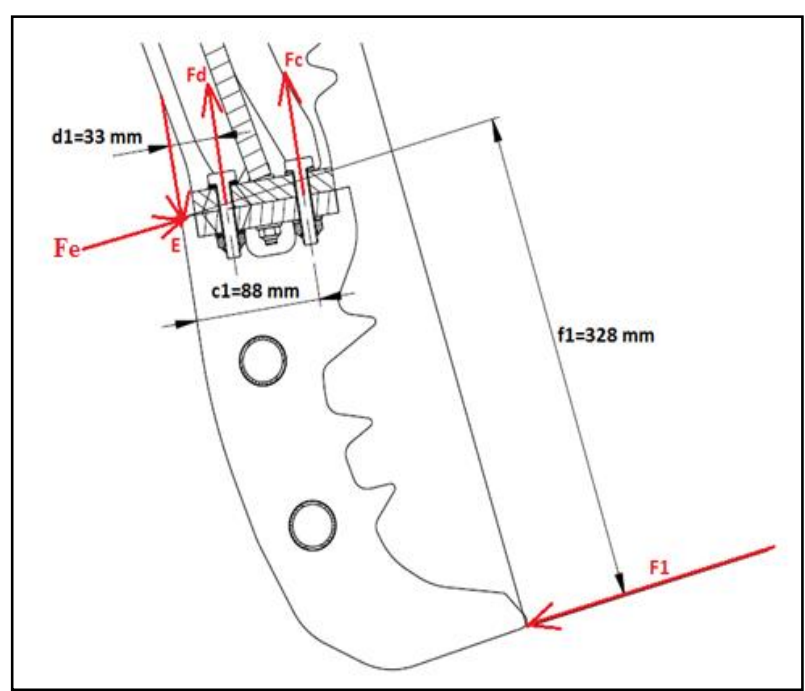

Şekil 22. Civatalara etki eden kuvvetleri bulmak için uç parçanın serbest cisim diyagramı

Etki eden F1 kuvvetini dengede tutma sırasında bu uç parça saat yelkovanı yönünde $\mathrm{E}$ noktası etrafinda dönmeye ve temas yüzeyinden sağdan sola doğru kaymaya çalışacaktır. Dönme sırasında cismin dengede durması için:

$\mathrm{F}_{c} c_{1}+\mathrm{F}_{\mathrm{d}} d_{1}=\mathrm{F}_{1} \mathrm{f}_{1}$

C ve D civata kuvvetleri birbirlerine tam eşit değildir. Aynı malzemeden yapıldıkları düşünülür ve parça yüzeyinin düz kalacağı varsayılarak her iki cıvata sirasında sehim:

$\frac{\delta_{D}}{d_{1}}=\frac{\delta_{C}}{c_{1}}$

$\mathrm{Bu}$ iki sırada cıvatalar aynı boyutta ve özellikte ise (Elastisite modülü, E, alan A ve uzunluk L aynı)

$\frac{F_{D}}{d_{1}}=\frac{F_{C}}{c_{1}}$ 
Moment denge denklemi ve bu denklem kullanılarak cıvata sıralarına gelen toplam $F_{C}$ ve $F_{D}$ çekme kuvvetleri hesaplanmıştır. (Her bir cıvataya gelen kuvvet bu sayının cıvata sayısına bölünmesi ile elde edilmiştir.)

Cıvataların kesmeye çalışması istenmez. Bu durumda cıvatalara ön gerilim verilmeli ve kesme yerine sürtünme kuvveti ile bu kuvvet taşınmalıdır. $\mathrm{Bu}$ durumda her bir cıvataya $\mathrm{N}$ kadar bir ön gerilim kuvveti verilir ise oluşacak olan sürtünme kuvveti: (cıvata sayısı $\mathrm{n}$ kabul edilmiştir.)

$\mu_{\mathrm{s}} \mathrm{nN}=\mathrm{F}_{1}$

$\mu$ s sürtünme katsayısı iki çelik yüzey arasındaki statik sürtünme katsayısı olan 0,6 alınmıştır. Buradan N ön gerilme kuvveti de bulunduktan sonra $\mathrm{C}$ ve $\mathrm{D}$ sıralarına dizilmiş dörder adet cıvatada, bir cıvataya gelen maksimum kuvvet $\left(\mathrm{F}_{\mathrm{c} 1}\right.$ veya $\left.\mathrm{F}_{\mathrm{d} 1}\right)$ ile ön gerilme kuvvetinin toplamı, kullanılacak olan cıvatanın kesit alanına bölünerek gerilme bulunmuştur. $\mathrm{Bu}$ gerilme emniyet katsayısı 3 alınarak cıvatanın akma mukavemetinden daha düşük olması beklenmiştir.

$\sigma=\frac{\mathrm{F}_{\mathrm{c} 1}+\mathrm{N}}{A}$

Cıvata kesit alanı belirlenirken cıvata diş dibi çapı esas alınmıştır. Burada cıvata için yapılan hesaplara uyduğu için altı köşe başlı DIN 933 M12x50-10.9 c1vata kullanılmıştır. Bu cıvata için:

$\sigma_{a k m a}=900 \mathrm{MPa}, \sigma_{\text {çekme }}=1000 \mathrm{MPa}$

\section{Analiz}

Hidrolik çeneye ait tüm parçaların mukavemet hesaplamaları sonlu elemanlar yöntemi kullanılarak MSC Marc\&Mentat yazılımı vasıtası ile gerçekleştirilmiştir. Hidrolik çenenin yükleme şartı belirlenerek çene üzerine gelen yükler tespit edilmiştir. Çene makine üzerinde iken en açık, orta ve en kapalı konumlar dikkate alınmak üzere analizler gerçekleştirilmiştir. Analiz bilgileri ise aşağıdaki gibidir:

- Elastisite Modülü: $210000 \mathrm{MPa}$

- Poisson Oranı: 0,3

- Yoğunluk: 7,85 gr/ $\mathrm{cm}^{3}$

- Çalışma basıncı: 230 bar

- Sinır Şartları: Ataşmanın makine kolu ile bağlantı noktasında tüm noktalardan sabitlenmiş, sadece rotasyon açık bırakılmıştır.

- Geometrik özellikler: Kabuk elemanlarla modellenmiştir.

- Eleman Tipi: quad4

- Eleman Sayısı: 20160

- Eleman Büyüklüğü: 9-10 mm

Analiz sonucunda hesaplanan gerilme değerleri kullanılan malzemelerin akma gerilmesinden küçük olduğu için yapılan tasarımın emniyetli olduğu belirlenmiştir. Elde edilen gerilme haritaları Şekil 2325 'te verilmiştir.

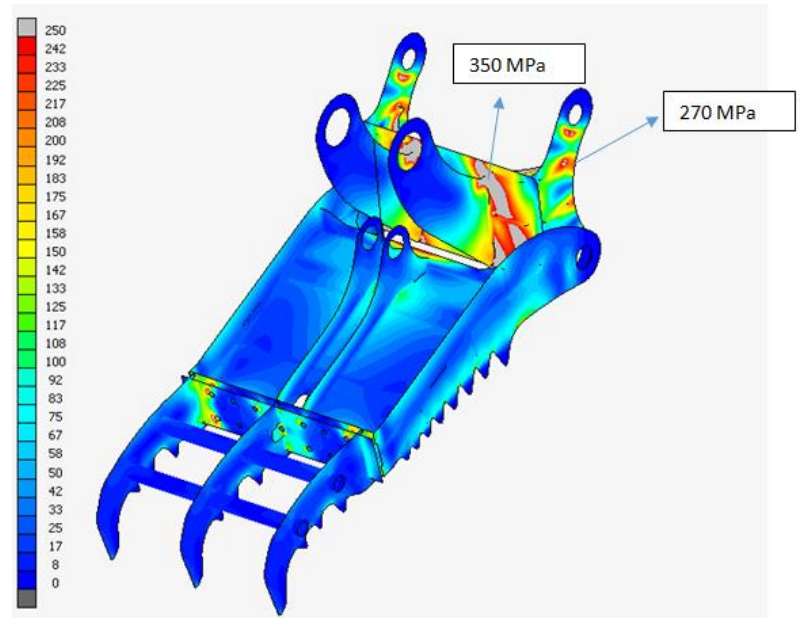

Şekil 23. Hidrolik çene silindiri en kapalı pozisyondayken çene üzerindeki gerilme haritası (Kapalı konum) (Von Mises)

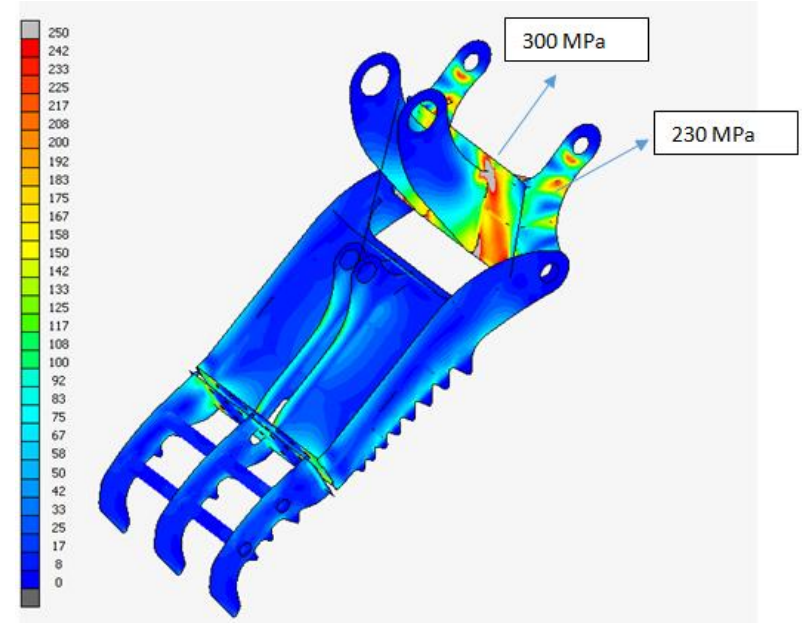

Şekil 24. Hidrolik çene silindiri $241 \mathrm{~mm}$ açık pozisyondayken çene üzerindeki gerilme haritası (Orta konum) (Von Mises)

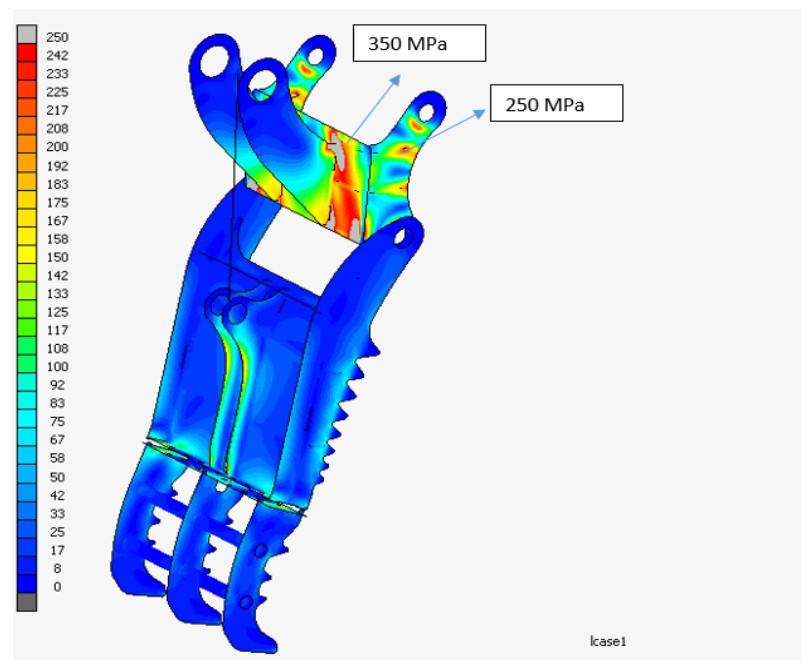

Şekil 25. Hidrolik çene silindiri en açık pozisyondayken çene üzerindeki gerilme haritası (Açık konum) (Von Mises) 
Böylece 230 bar çalışma basıncında uç ile dönme ekseni arasındaki doğrultuya sürekli dik olacak şekilde koparma kuvveti uygulanmıştır. Hidrolik çene silindirinin en kapalı konumdan en açık konuma gelene kadar gerilmeler incelenmiştir. Özellikle hidrolik çene silindiri en kapalı pozisyonda iken gerilmelerin en yüksek olduğu görülmüştür.

\section{Test}

Hidrolik çene ataşman elemanları üretildikten sonra testi yapılmak üzere seçilen Hidromek marka kazıcı yükleyici makineye montajı yapılmıştır (Şekil 26). Analiz koşullarına en yakın şekilde test düzeneği hazırlanmıştır. Burada analizde görülen iki adet en yüksek gerilme bölgesi ile bir adet de normal gerilme bölgesi olmak üzere ataşmana toplam 3 adet gerilimölçer yapıştırılmıştır. LMS Scadas cihazı vasıtasıyla ilgili bölgelerde gerilimler ölçülmüştür [19].
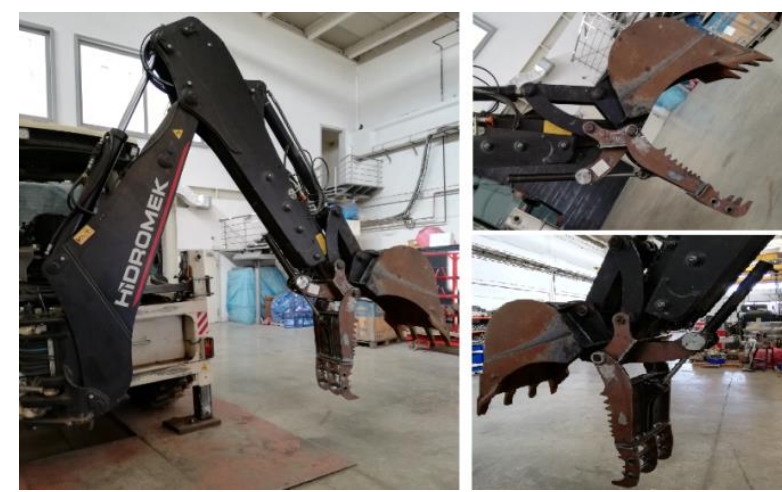

Şekil 26. Hidrolik çene ataşmanının makineye montajı

Hidrolik çene ataşmanı üzerinde üç doğrultuda ölçüm yapan birim uzama elemanlarının olduğu rozet olarak tanımlanan elemanların ataşman üzerinde ilgili bölgelere yapıştırılarak testi yapılmıştır. Çok eksenli gerilme durumu olduğundan klasik tip basit birim uzama bantları yerine rozet tipi gerilim ölçerler kullanılmıştır Gerinim ölçerlerin yerleri Şekil 27'de görülmektedir [20].

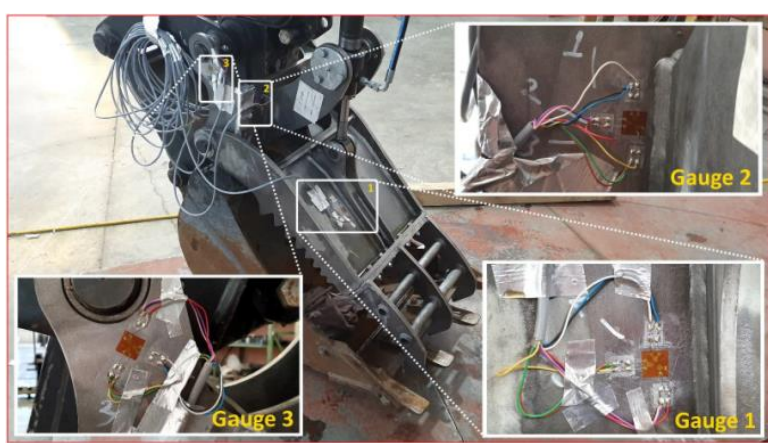

Şekil 27. Gerilim-ölçerlerin hidrolik çene ataşmanı üzerindeki yerleri

Gerilme bantları yapıştırılan ataşman sonlu elemanlar yöntemi ile analiz koşullarındaki gibi çenenin en açık (silindir tam kapalı strokta), orta (silindir orta strokta) ve en kapalı (silindir tam açık strokta) konumda olduğu durumda uç kısmından çeneye yaklaşık $90^{\circ}$ olacak şekilde araya cisim yerleştirilerek kazıcı kepçe sabit olacak şekilde çene hidrolik silindirin açma kuvveti ile zorlanmıştır.

$\mathrm{Bu}$ işlemler yapılırken silindirde oluşan basıncın kontrolü üzerine montajlanan basınç portları sayesinde takip edilmiştir. Silindir çalışma basıncı 220-230 bar arasında ölçülmüştür.

\section{TARTIŞMA}

Literatür çalışması yapılarak tasarım kriterleri belirlenen ve ardından tasarım hesaplarının sonlu elemanlar yöntemi ile analiz edilerek doğrulandığı hidrolik çene ataşmanı, son olarak da analiz koşullarına en yakın olacak şekilde gerilim-ölçerler ile teste tabi tutularak analiz doğrulaması yapılmıştır. Test sırasında analizde olduğu gibi çenenin açık, orta ve kapalı konumlarında çene ucuna dik etki edecek şekilde kuvvet uygulanmıştır (Şekil 28).

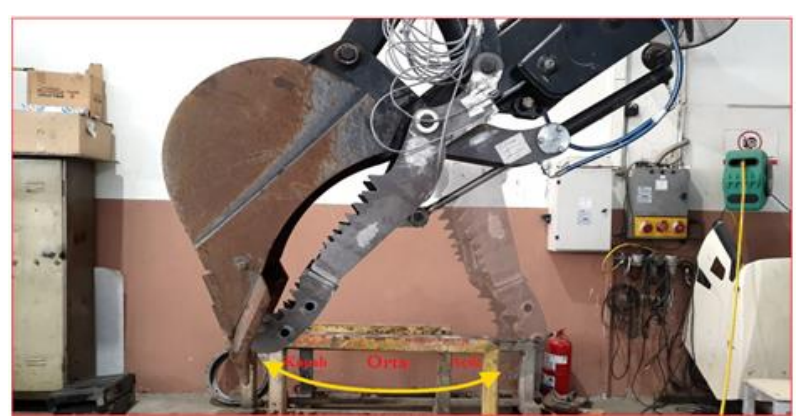

Şekil 28. Hidrolik çenenin açık, orta ve kapalı konumu

Buna göre belirlenen üç bölgede oluşan gerilmelerin analiz ve test kıyaslamaları Şekil 29,30 ve 31 'de gösterilmiştir.

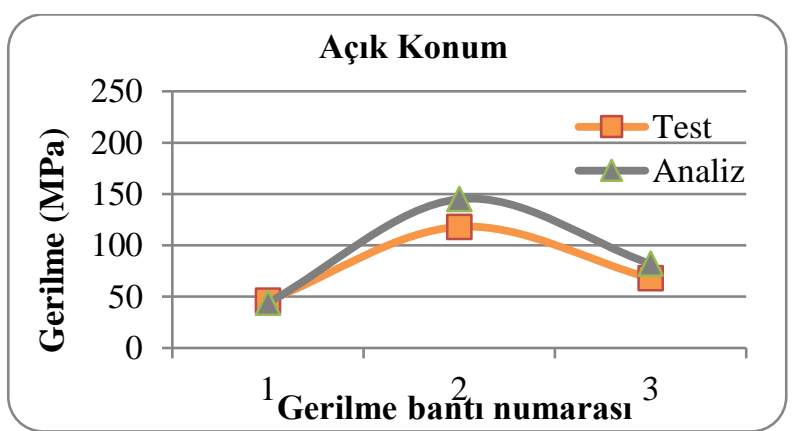

Şekil 29. Hidrolik çenenin açık konumda analiz ve test değerlerinin kıyaslanması

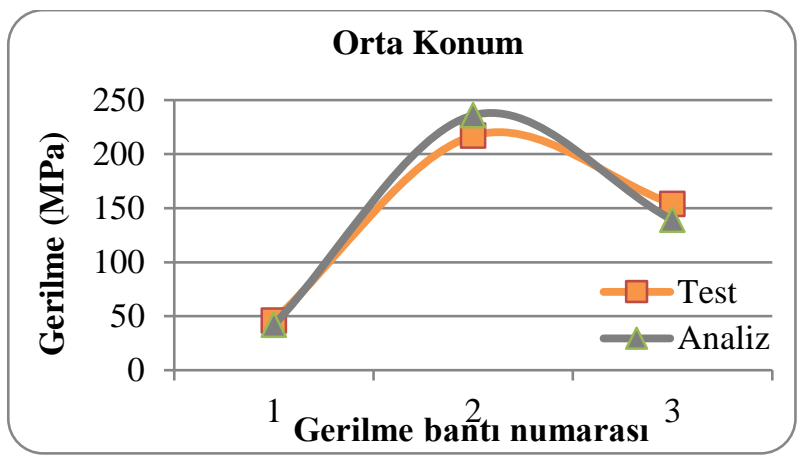

Şekil 30. Hidrolik çenenin orta konumda analiz ve test değerlerinin kıyaslanması 


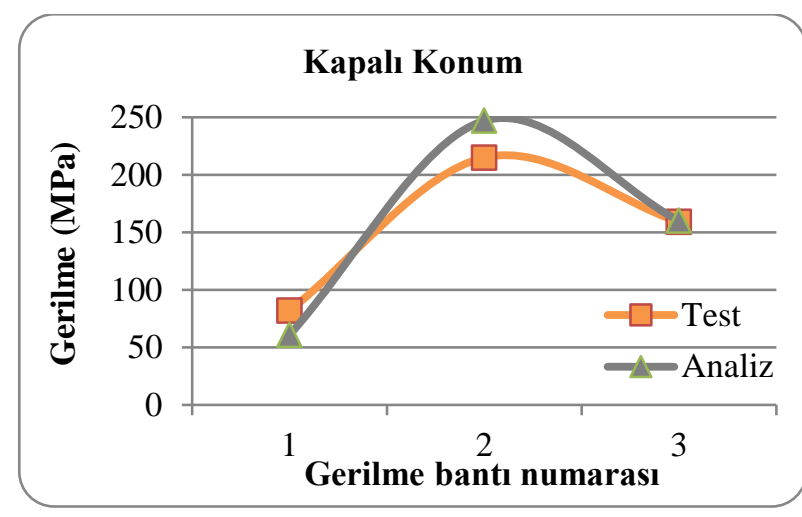

Şekil 31. Hidrolik çenenin kapalı konumda analiz ve test değerlerinin kıyaslanması

Tüm test gerilme ölçüm değerleri ile sonlu elemanlar analiz değerleri arasında ortalama $\% 11,74$ hata oranı olmuştur. $\mathrm{Bu}$ hatanın olası nedenlerinden bazıları:

- Hidrolik çene üretim toleransları

- Rozet imalindeki ufak hatalar

- Testte analiz koşullarının birebir gerçekleştirilememiş olması

- Test sırasında silindir çalışma basıncının sabit 230 barda olmaması

- Özellikle kapalı konum olmak üzere test sırasında analizdeki gibi kuvvet tam olarak çene ucundan çeneye dik olacak şekilde verilememesi

- Parçalara rozet yapıştırılmasında oluşabilecek hatalar

- Sonlu elemanlar analizinde küçük modelleme hatalar1

şeklinde ifade edilebilir.

Ayrıca genel olarak analiz değerlerinin test değerlerinden yüksek hesaplanması bu ataşmanın tasarım sürecinde güvenli bölgede kalınmış olması olarak da yorumlanabilir.

\section{SONUÇ}

Bu çalışmada kazıcı yükleyici iş makineleri için hidrolik tahrikli çene ataşman tasarımı, sonlu elemanlar analizi ve gerilim ölçüm testi gerçekleştirilmiş̧ir. Önce makine üzerinde hidrolik çene ataşmanı yokken makinenin kazıcı kaldırma kapasitesinin maksimum olduğu noktadaki kaldırma ağırlığı hidrolik çene makineye montajlandıktan sonra da çene ile bu ağırlığı kaldırabilecek şekilde tasarım hesapları yapılmıştır. Hidrolik çenenin makine ana komponentlerinde herhangi bir deformasyon gerçekleştirilmeksizin, direk montajlanabilir olması ve çene ucunun tamamen gövdeden ayrılmaksızın $180^{\circ}$ döndürülerek malzeme tutma işlevinin dışında malzeme sökme işlevi de kazanması ile farklılık yaratılmıştır.

Ataşmanın gerçek çalışma koşullarında çok nadir karşılaşacağı çenenin en uç noktasından gövdeye dik doğrultuda kuvvetin uygulanması ile tasarım hesapları ve sonlu elemanlar yöntemi ile analiz yapılmıştır. $\mathrm{Bu}$ yükleme şartı çene üzerine gelebilecek maksimum kuvvetleri oluşturduğu için seçilmiştir. Hidrolik çene silindirinin tüm strok değerlerinde bu yükleme şartı korunmuştur. Genel olarak da hidrolik çenenin tam kapalı, orta ve tam açı pozisyonlarında üzerindeki gerilmeler incelenmiştir.

Test sirasında en yüksek gerilim değeri $217 \mathrm{MPa}$ ile çene orta konumda iken bağlantı braketi üzerindeki silindir bağlantı uzuvlarının kaynak bölgesine yakın olan bölgede okunmuştur. $\mathrm{Bu}$ durum analizlerde görüldüğü için aşınma bölgesi olmamasına rağmen bağlantı braketi akma mukavemeti yaklaşı $1000 \mathrm{MPa}$ olan aşınmaya dayanıklı saclardan üretilmesi kararı isabetli olmuştur. Böylece analizden önce SAE $\mathrm{S} 355 \mathrm{~J} 2 \mathrm{C}+\mathrm{N}$ malzemeden tasarlanan bağlantı braketi analizden sonra malzemesi değiştirilerek okunan gerilme değerlerine dayanımı sağlanmıştır.

Analizlerde bu üç pozisyonda görülen maksimum gerilme değerlerine göre iki nokta ve bir de çenede farklı bölgede bir nokta alınacak şekilde üretilen çene üzerine gerilim-ölçerler yapıştırılmıştır. Hidrolik silindirin çalışma basınç değeri de kontrol altına alınarak bu üç bölgede oluşan gerilme değerleri kaydedilmiştir. Analiz ve test değerleri karşılaştııılmışıı. Test şartlarının tam olarak analiz şartlarını oluşturamaması göz önüne alındığında genel olarak ilgili bölgelerde analiz ve test değerleri uyum sağladı. Genele bakıldığında da analiz değerlerinin test değerleri üzerinde çıkması ile güvenli bölgede kalınmış oldu. Sonuç olarak üretilen çenenin malzeme akma mukavemetinin altında değerler ölçüldüğü ve tasarım ile analizlerde öngörülen değerlerin üstünde bir sonuçla karş̧laşılmadığı için tasarım testi başarı ile tamamlamıştır.

$\mathrm{Bu}$ tasarımdan farklı olarak operatörlerin de üzerinde ortak görüş bildirdiği hidrolik çene makine üzerine montajlı iken de kazıcı kepçeyi tam anlamı ile kazı işlerinde kullanabilir bir tasarım üzerinde çalışma yapılabilir.

\section{TEŞEKKÜR}

Çalışmada cihaz, malzeme, teknik destek gibi birçok imkân HIDROMEK A.Ş. tarafindan sağlanmıştır, teşekkürü bir borç bilirim.

\section{ORCID}

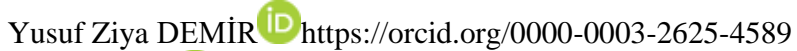

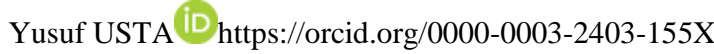




\section{KAYNAKÇA}

[1] Kılıç, B., Balkan, T., Söylemez, E. Kazıcı-yükleyici iş makinasının hidrolik ve mekanik sistemlerinin dinamik analizi, V. Ulusal Hidrolik Pnömatik Kongresi, Sayfa 13, İzmir, 2008.

[2] Akpınar, M.V. İş makineleri ders notları, Karadeniz Teknik Üniversitesi, Sayfa 1-2, Trabzon, 2010.

[3] Söylemez, E. Mekanizma Tekniği Makine Teorisi-1, Birsen Yayınevi, Bölüm 1, 2010.

[4] JCB Kazıcı yükleyici makineler, www.sifjcb.com.tr/urunler/makina-gruplari/kazici-yukleyiciler.

[5] Broken tractor machinery parts, https://www.brokentractor.com/

[6] Extreme metal products, https://extrememetalproducts.com/

[7] Alibaba global trade, https://turkish.alibaba.com/trade/search?fsb=y\&IndexArea=prod uct_en $\&$ CatId $=\&$ SearchText=backhoe+thumb

[8] Everything https://www.everythingattachments.com/

attachments,

[9] Draco equipment, http://www.dracoequipment.com/index.htm

[10] Earth moving machinery, Safety, Requirements for backhoe loaders, DIN EN 474-4, 2006.

[11] Excavator hydraulic type thumb clamp mechanism and excavator work device, CN105256851A numaralı patent, 2016.
[12] Kepçeye bağlantılı çene tasarımı, JP2003213718A numaralı patent, 2003Söylemez E. Mekanizma tekniği makine teorisi-1, Birsen Yayınevi, Sayfa 57-77, İstanbul, 2010.

[13] Yener M. Design of a computer interface for automatic finite element analysis of an excavator boom. Yüksek Lisans Tezi, Sayfa 11-18. Orta Doğu Teknik Üniversitesi, Ankara, 2005.

[14] Arslan M., Serer M. Hidrolik silindir tasarım ve imalatında kullanılan toleranslar ve formüller. 3. Ulusal Hidrolik Pnömatik Kongresi, İzmir, 2003.

[15] Valansi A. Hidrolik kreyn tasarımı. Yüksek Lisans Tezi, Yıldız Teknik Üniversitesi, Sayfa 18-87, İstanbul, 2008.

[16] Çelik borular, Hassas uygulamalar için, Teknik teslim şartları, Bölüm 3, Kaynaklı soğuk çekilmiş borular, TS EN 10305-3, 2012.

[17] Yener M., Fıçıcı F., Söylemez E, Arıkoğlu T. İş makinaları konstrüksiyonlarının tasarımında bilgisayar ortamında sonlu eleman analizi metoduyla mukavemet analizlerinin yapılması ve önemi, İş makinaları sempozyumu bildiri kitapçığı, 2003.

[18] Köse H.T. Kazıcı Yükleyici İş Makinesi Ön Aks Tasarımı ve Tasarımın Deneysel Doğrulanması, Yüksek Lisans Tezi, Gazi Üniversitesi,Ankara, 2014 . 